\title{
Field evaluation of synthetic insecticides against Capitulum borer (Helicoverpa armigera) infesting Sunflower (Helianthus annus L.)
}

\author{
Muhammad Aftab ${ }^{1}$, Muhammad Kamil Malik ${ }^{1}$, Muhammad Zubair ${ }^{1 *}$, \\ Sikander Ali $^{1}$, Muhammad Waqas ul Hassan ${ }^{2}$, Kanwal Hanif ${ }^{3}$, Huma \\ Qamar $^{1}$ and Muhammad Rizwan Khurshid ${ }^{1}$ \\ 1. Oilseeds Research Institute, Faisalabad-Pakistan \\ 2. Pest Warning and Quality control of Pesticides, Bhakkar-Pakistan \\ 3. Entomological Research Institute, Faisalabad-Pakistan \\ *Corresponding author's email: chzubair92@gmail.com \\ Citation \\ Muhammad Aftab, Muhammad Kamil Malik, Muhammad Zubair, Sikander Ali, Muhammad Waqas ul Hassan, \\ Kanwal Hanif, Huma Qamar and Muhammad Rizwan Khurshid. Field evaluation of synthetic insecticides \\ against Capitulum borer (Helicoverpa armigera) infesting Sunflower (Helianthus annus L.). Pure and Applied \\ Biology. Vol. 9, Issue 3, pp1800-1806. http://dx.doi.org/10.19045/bspab.2020.90191
}

\begin{tabular}{|c|c|c|c|}
\hline Received: $13 / 02 / 2020$ & Revised: $24 / 04 / 2020$ & Accepted: 27/04/2020 & Online First: $28 / 04 / 2020$ \\
\hline
\end{tabular}

\section{Abstract}

In the economy of Pakistan, oilseed crops play a major share and contribute more than $17 \%$ to meet the domestic edible oil requirement. Sunflower contributes about $11 \%$ in domestic edible oil production. However, a wide gap exists in this sector which can be improved for enhancing its local production. Several factors are responsible for the yield losses. Losses due to insect pests are increasing because of overusing the insecticides. On the other hand, insects are also developing resistance against insecticides at a significant rate. The present study was designed to identify the most effective insecticide for inclusion in Integrated Pest Management (IPM) program to effectively manage capitulum borer (Helicoverpa armigera) infesting Sunflower. Maximum mortality $(83.28 \%$ ) was expressed by Spinetoram followed by Chlorantraniliprole (81.53\%), Emamectin Benzoate (78.23\%), Indoxacarb (75.13\%) and Lufenuron (69.67\%). These insecticides can alternatively be used to control capitulum borer. However, further research is required to ensure effective management of capitulum borer through IPM.

Keywords: Coragen; Efficacy; Emamectin; Head moth; Spinetoram; Sunflower

\section{Introduction}

Sunflower (Helianthus annuus L.) is a prime oilseed crop. In sub-continent, its cultivation started in sixteenth century. It is fourth important oilseed crop worldwide [1]. Sunflower seed possesses $48 \%$ oil content which can be easily refined having low cholesterol level besides vitamins like A, D, E and K. It comprises of about $27 \%$ proteins. Its oil is helpful in prevention of cardiac diseases and is highly recommended to heart patients for daily use $[2,3]$. The linoleic acid found in its oil has anti-carcinogenic properties [4]. Sunflower oil is used for household cooking, production of vanaspati ghee, paints, soaps and in cosmetics industries. Its cake is also liked by animals as best nutritious feed [3]. In Pakistan, sunflower is cultivated in two growing seasons: spring and autumn. It is best fit in local crop rotation programs. It ranks third in oil seed crops, primarily on 
the basis of area coverage and oil production in Pakistan. It is cultivated on an area of 28 thousand hectares resulting in 38 thousand tons seed and 54 thousand tons edible oil. Pakistan imports about $80 \%$ of required edible oil (1.455 billion US Dollars) to meet local needs. It is the crop which can reduce the gap between the demand and supply of cooking oil and is also well adapted to our climatic conditions [5]. However, obtained yield per hectare is low as compared to other countries of the world. There are many aspects which can be held responsible for stumpy yield. These include lack of awareness about production technology, shortage of certified seed, high temperature, poor cultural practices, drought, lack of canal irrigation water, poor marketing, low industrial utilization, lack of small scale harvesting machinery, adverse climatic conditions, diseases and insect pests [6-8].

About 251 insect pests and acarine pests have been recorded on sunflower worldwide [9]. In Pakistan, many insect pests, viz; cutworm, jassid, thrips, whitefly, cotton aphid, green stink bug, saw toothed beetle, hairy caterpillar, cabbage semilooper, armyworm, epilachna beetle and capitulum borer feed on this crop [10, 11]. Capitulum borer also known as Head moth or Head borer, Helicoverpa armigera (Hubner) is menacing polyphagous key insect pest of this crop, which is cosmopolitan in distribution [12]. It has about 180 hosts including many economically important crops such as cotton, pulses, fruits, vegetables etc. [13]. Its larvae feed on foliage and flowers for little time. These usually create hole in head, seeds and make tunnel in head. After damaging one head, larvae shift to next one feeding which causes the loss. $3^{\text {rd }}$ and $4^{\text {th }}$ instar larvae cause severe damage. It can cause $25 \%$ yield losses generally and in rigorous infestation $40-70 \%$ yield loss is common. 1 larvae/5 head can cause economic loss, therefore, this number of infestation is considered as economic threshold level [14]. So, effective management is today's need.

Various methods viz; cultural practices, mechanical techniques, biocontrol and chemical application are common tactics. Mostly, insecticides are recommended to manage this notorious pest to gain immediate control [15]. About $75 \%$ insecticides are applied to control this pest that's why resistance is developed against conventional insecticides groups like Pyrethroids, [16] Organophosphates (Ops), and carbamates [17]. Besides this, these insecticides are also harmful to our natural enemies as they are broad spectrum in nature. It is need of the hour to apply new chemistry insecticides which are also environment friendly [18].

The present study was conducted in field conditions to evaluate the commonly used insecticides to control capitulum borer Helicoverpa armigera (Hub.) infesting sunflower. Aim of the study was to identify the most effective insecticide against this insect pest.

\section{Materials and methods}

Sunflower hybrid (FH-516) seeds were obtained from the Oilseeds Research Institute (ORI), Ayub Agricultural Research Institute (AARI), Faisalabad and were sown at the research area of the same Institute during two consecutive crop growing seasons; 2018 and 2019. Randomized complete block design (RCBD) having three replications was adopted.

\section{Crop husbandry}

Sowing on ridges was completed on January 25, 2018 and on February 02, 2019 respectively. Row to row and plant to plant distances were maintained at 75 and 9 inches respectively. Pre-emergence weedicide, Pendimethalin was sprayed at the rate of $800 \mathrm{ml}$ in $120 \mathrm{~L}$ water per acre by using battery powered sprayer immediately after sowing.

Irrigations were provided 20 days after emergence, 20 days after first irrigation, at flowering and at seed development stage respectively. $\mathrm{N}: \mathrm{P}: \mathrm{K}$ were provided at the 
rate of 48:34:25 kg/acre. Phosphorus and Potash were provided during seed bed preparation. Nitrogen was provided at first two irrigation and at flowering stage in split quantities.

Thinning was completed when crop reached at 4-leaf stage. Earthing up was done when the crop gained height of 30 inches. Crop was harvested on May 15, 2018 and May 25, 2019 respectively.

\section{Data recording}

Data for sunflower capitulum borer were recorded on five randomly selected plants $[19,20]$ when capitulum borer infestation was observed. Tested insecticides (Table 1) were applied in three replicates Five plants from each treatment were randomly selected, tagged and data regarding insect population were recorded. Insect population was recorded before insecticide application. After the application of treatments, mortality data were recorded at 24-hour, 48-hour and 72-hours' time intervals. The experiment was repeated thrice to minimize possible error in each year. Percentage mortality of capitulum borer was calculated by using the formula:

Mortality $(\%)=\{($ Pre-Treatment Population - Post-Treatment Population $) /$ Pre-Treatment Population $\}$ x 100

Table 1. Information about evaluated insecticides

\begin{tabular}{|c|c|c|c|c|c|}
\hline $\begin{array}{l}\text { Sr } \\
\#\end{array}$ & IRAC Classification & $\begin{array}{l}\text { Mode of } \\
\text { Action }\end{array}$ & $\begin{array}{c}\text { Insecticide } \\
\text { (Brand Name) }\end{array}$ & Formulation & Dose/acre \\
\hline 1 & $\begin{array}{l}\text { Nicotinic acetylcholine } \\
\text { receptor (NAChR) } \\
\text { Allosteric modulators-Site I } \\
\text { Subgroup: Spinosyns }\end{array}$ & $\begin{array}{l}\text { Nerve } \\
\text { Action }\end{array}$ & $\begin{array}{l}\text { Spinetoram } \\
\text { (Radiant) }\end{array}$ & $120 \mathrm{SC}$ & $80 \mathrm{ml}$ \\
\hline 2 & $\begin{array}{l}\text { Ryanodine receptor } \\
\text { modulators } \\
\text { Subgroup: Diamides }\end{array}$ & \multirow{2}{*}{$\begin{array}{l}\text { Nerve and } \\
\text { muscle } \\
\text { action }\end{array}$} & $\begin{array}{l}\text { Chlorantraniliprole } \\
\text { (Coragen) }\end{array}$ & $20 \mathrm{SC}$ & $80 \mathrm{ml}$ \\
\hline 3 & $\begin{array}{c}\text { Glutamate-gated chloride } \\
\text { channel (GluCl) allosteric } \\
\text { modulators } \\
\text { Subgroup: Avermectins }\end{array}$ & & $\begin{array}{l}\text { Emamectin } \\
\text { Benzoate } \\
\text { (Proclaim) }\end{array}$ & $1.9 \mathrm{EC}$ & $200 \mathrm{ml}$ \\
\hline 4 & $\begin{array}{l}\text { Voltage-dependent sodium } \\
\text { channel blockers } \\
\text { Subgroup: Oxidiazines }\end{array}$ & $\begin{array}{l}\text { Nerve } \\
\text { Action }\end{array}$ & $\begin{array}{l}\text { Indoxacarb } \\
\text { (Steward) }\end{array}$ & $150 \mathrm{EC}$ & $175 \mathrm{ml}$ \\
\hline 5 & $\begin{array}{c}\text { Inhibitors of Chitin } \\
\text { Biosynthesis affecting CHS } 1 \\
\text { Subgroup: Benzoylureas }\end{array}$ & $\begin{array}{l}\text { Growth } \\
\text { Regulator }\end{array}$ & $\begin{array}{l}\text { Lufenuron } \\
\text { (Match) }\end{array}$ & $50 \mathrm{EC}$ & $100 \mathrm{ml}$ \\
\hline 6 & \multicolumn{3}{|c|}{ Control } & \multicolumn{2}{|c|}{ Untreated } \\
\hline
\end{tabular}

\section{Data analysis}

The relevant data were tabulated and analyzed using Statistix 8.1 software, analysis of variance was constructed and treatments' mean comparisons were made through Tuckey's Honestly Significant Difference (HSD) test at 0.05 significance level.

\section{Results and discussion}

Spinetoram is a new chemistry insecticide having nerve action as its mode of action against insect pests. In first year of the study, it gave mortality as similar as in case of Emamectin Benzoate and Lufenuron (Table 2) when data recorded after 24 hours of treatment application. In second year of study, no significant difference in mortality was found in all the tested insecticides. Same was the case when data were recorded after 48 and 72 hours of treatment in both the years. This is clearly visible from (Table 2) that all the insecticides expressed 
different mortality in both the years but when it was statistically analyzed, there was no major significant difference in both study years.

All the recorded data of mortality caused by the insecticides was cumulated and statistically analyzed cumulatively (Table 3). Table 3 shows that no significant difference in mortality was found when data were recorded after 48 and 72 hours of treatment. However, significant differences were recorded when data recorded after 24 hours of insecticide application. Maximum mortality (41.48\%) was caused by Chlorantraniliprole followed by Indoxacarb (32.56\%), Emamectin Benzoate (31.37\%) and Lufenuron (30.33\%) which are statistically similar with each other. But, mortality caused by spinetoram $(30.50 \%)$ was statistically different as compared to other insecticides.

Spinetoram was field tested against Helicoverpa armigera and it gave $80.3 \%$ and $83.2 \%$ mortality in two consecutive years [21] while in present study, it expressed $83.28 \%$ larval mortality (Table 3) which is very close to each other. Spinetoram gave $71.42 \%$ mortality when tested against Helicoverpa armigera in chickpea [22]. In present study, spinetoram gave maximum mortality $(84.21 \%)$ in second year of the study which indicates that considerable level of resistance in Helicoverpa armigera has been developed against spinetoram in some specific areas as both studies are from different provinces of country.

Chlorantraniliprole is a commonly used insecticide affecting nerve and muscles of target insects. This insecticide was tested on Helicoverpa armigera infesting tomato crop and $70 \%$ mortality was observed after 96 hours of insecticide application [23]. They also observed $72 \%$ mortality in another district of Punjab Province. They calculated cumulative mortality of Chlorantraniliprole which was $71 \%$. In the present study, $81.53 \%$ was cumulative mortality. The difference in both the mortality percentages might be due to difference in environmental conditions and difference in crop. [24] also evaluated the same insecticide against same insect on tomato crop and Chlorantraniliprole expressed $92.12 \%$ mortality when data were recorded after 72 hours of treatment. [25] evaluated the efficacy of Chlorantraniliprole against Helicoverpa armigera on chickpea and found $85 \%$ mortality after 72 hours of treatment which is very close to the mortality found in the present study $(81.53 \%)$ as formulation and dose rate in both the studies was similar to some extent. It is also evident that even after 4-5 years of insecticide' extensive use on the field, no significant signs of resistance developed against this particular insecticide.

Emamectin benzoate was tested in field and it expressed $75 \%$ mortality after 72 hours of treatment against Helicoverpa armigera infesting chickpea [26]. In the present study, $78.23 \%$ mortality was witnessed which is as similar as the already published results (Table 3). This insecticide was also field tested in sunflower and it expressed $95.93 \%$ and $93.75 \%$ mortality in two consecutive years [27] while in present study it expressed $78.23 \%$ cumulatively (Table 3). This difference in observed mortality percentages might be due to the difference in locality, the environmental conditions or decrease in susceptibility of Helicoverpa armigera.

Indoxacarb is a nerve action poison. It minimized percent infestation of Heliothis armigera for only $7.5 \%$ [28] when its dose rate was $105 \mathrm{ml} /$ acre. In the present study, treatment was applied at the dose rate of $175 \mathrm{ml}$ per acre which caused $75.13 \%$ mortality of Helicoverpa armigera on Sunflower. [29] evaluated bio-efficacy of indoxacarb and about $80 \%$ mortality was found which is close to the mortality witnessed in the present study (Table 3). 
Table 2. Mortality of Capitulum borer at various time intervals

\begin{tabular}{|c|c|c|c|c|c|c|c|c|c|}
\hline \multirow{3}{*}{$\begin{array}{c}\text { Sr. } \\
\#\end{array}$} & \multirow{3}{*}{ Insecticide } & \multirow{2}{*}{\multicolumn{2}{|c|}{$\begin{array}{c}\text { Insect } \\
\text { Population } \\
\text { Before } \\
\text { Treatment } \\
\end{array}$}} & \multicolumn{6}{|c|}{ Mortality (\%) } \\
\hline & & & & \multicolumn{2}{|c|}{24 НАТ* $*$} & \multicolumn{2}{|c|}{48 НAT* } & \multicolumn{2}{|c|}{72 НAT* } \\
\hline & & 2018 & 2019 & 2018 & 2019 & 2018 & 2019 & 2018 & 2019 \\
\hline 1 & Spinetoram & 1.13 & 1.27 & $29.41 \mathrm{ab}$ & $31.58 \mathrm{a}$ & $64.71 \mathrm{~b}$ & $63.16 \mathrm{~b}$ & $82.35 b$ & $84.21 \mathrm{~b}$ \\
\hline 2 & Chlorantraniliprole & 0.73 & 1.06 & $45.45 \mathrm{~b}$ & $37.50 \mathrm{a}$ & $63.64 \mathrm{~b}$ & $56.25 \mathrm{~b}$ & $81.82 b$ & $81.25 \mathrm{~b}$ \\
\hline 3 & $\begin{array}{l}\text { Emamectin } \\
\text { Benzoate }\end{array}$ & 1.00 & 1.13 & 33.33ab & $29.41 \mathrm{a}$ & $66.67 \mathrm{~b}$ & $64.71 b$ & $80.00 \mathrm{~b}$ & $76.47 \mathrm{~b}$ \\
\hline 4 & Indoxacarb & 0.87 & 1.00 & $38.46 \mathrm{~b}$ & $26.67 \mathrm{a}$ & $53.85 \mathrm{~b}$ & $53.33 \mathrm{~b}$ & $76.92 b$ & $73.33 b$ \\
\hline 5 & Lufenuron & 1.13 & 1.06 & 29.41ab & $31.25 \mathrm{a}$ & $58.82 \mathrm{~b}$ & $50.00 \mathrm{~b}$ & $70.59 \mathrm{~b}$ & $68.75 b$ \\
\hline 6 & Control & 1.06 & 1.20 & $-6.25 a$ & $0.00 \mathrm{a}$ & $-12.12 \mathrm{a}$ & $-5.56 a$ & & $-5.55 a$ \\
\hline & HSD@ $9 \%$ & & & 2.82 & 3.01 & 2.99 & 2.58 & 3.21 & 2.23 \\
\hline
\end{tabular}

*HAT= Hours after Treatment of insecticide.

$* *=$ Negative sign indicates the relative increase in insect population.

Means sharing similar letter are not significantly different from each other while Means representing different letters within a box of column are significantly different to some extent from other means at $\mathrm{P}<0.05$

Table 3. Cumulative Mortality (\%) of Capitulum borer

\begin{tabular}{|c|c|c|c|c|c|}
\hline \multirow{2}{*}{$\begin{array}{c}\text { Sr. } \\
\#\end{array}$} & \multirow{2}{*}{ Insecticides } & Population before & \multicolumn{3}{|c|}{ Mortality Percentage } \\
\cline { 4 - 6 } & & treatment & 24 HAT* & 48 HAT* & 72 HAT* $^{*}$ \\
\hline 1 & Spinetoram & 1.20 & $30.50 \mathrm{ab}$ & $63.93 \mathrm{~b}$ & $83.28 \mathrm{~b}$ \\
\hline 2 & Chlorantraniliprole & 0.90 & $41.48 \mathrm{~b}$ & $59.94 \mathrm{~b}$ & $81.53 \mathrm{~b}$ \\
\hline 3 & Emamectin Benzoate & 1.06 & $31.37 \mathrm{~b}$ & $65.69 \mathrm{~b}$ & $78.23 \mathrm{~b}$ \\
\hline 4 & Indoxacarb & 0.93 & $32.56 \mathrm{~b}$ & $53.59 \mathrm{~b}$ & $75.13 \mathrm{~b}$ \\
\hline 5 & Lufenuron & 1.10 & $30.33 \mathrm{~b}$ & $54.41 \mathrm{~b}$ & $69.67 \mathrm{~b}$ \\
\hline 6 & Control & 1.13 & $-3.12 \mathrm{a}$ & $-9.03 \mathrm{a}$ & $-9.02 \mathrm{a}$ \\
\hline \multicolumn{2}{|c|}{ HSD@ 5\% } & 1.89 & 2.05 & 1.97 \\
\hline
\end{tabular}

*HAT= Hours after Treatment of respective insecticide.

$* *=$ Negative sign indicates the relative increase in insect population

Means sharing similar letter are not significantly different from each other at $\mathrm{P}<0.05$

Lufenuron is a growth regulator insecticide and it gave $56.02 \%$ mortality after 96 hours of treatment [23] while in present study it was witnessed to have expressed $69.67 \%$ mortality (Table 3). This difference is might be due to difference in formulation of insecticide product which was used in the present study along with differences in locality and crop. This insecticide was tested against same insect on chickpea and it revealed $65 \%$ mortality when data were recorded after 72 hours of treatment [25] which is near to the mortality found in the present study.

\section{Conclusion}

Spinetoram showed maximum mortality of capitulum borer (Helicoverpa armigera) followed by Chlorantraniliprole, Ememctin Benzoate, Indoxacarb and Lufenuron respectively. There was no significant difference in percent mortality caused by these insecticides after 72 hours of treatment. However, Spinetoram expressed different response after 24 hours of treatment. This shows that these insecticides can be used as alternatives to each other in IPM program to effectively control capitulum borer (Helicoverpa armigera) as per requirement. Moreover, the chances of increase of resistance development in capitulum borer to some specific insecticides will be minimized.

\section{Authors' contributions}

Conceived and designed the experiments: $S$ Ali \& M Aftab, Performed the experiments: MK Malik, M Zubair \& MR Khurshid, Analyzed the data: MK Malik, K Hanif \& 
H Qamar, Wrote the paper: MWU Hassan \& M Zubair.

\section{References}

1. Skoric D, Jocic S, Lecic, N \& Sakac Z (2007). Development of sunflower hybrids with different oil quality. Helia, 30(47): 205-212.

2. Razi H \& Asad MT (1998). Evaluation of variation of agronomic traits and water stress tolerant in sunflower conditions. Agric Nat Resour Sci 2(2): 31-43.

3. Hussain MK, Rasul E \& Ali SK (2000). Growth analysis of sunflower under drought conditions. Int J Agri Bio 2(2): 136-140.

4. Bauman DE, Barbano DA, Dwyer DA \& Giriinari JM (2000). Technical Note: production of butter with enhanced conjugated linoleic acid for use in biomedical studies with animal models. J Dairy Sci 83: 2422-25.

5. Government of Pakistan. Ministry of Finance. Economic Survey of Pakistan 2018-19.

6. Burney $\mathrm{K}$, Ahmad I \& Aslam M (1991). Charcoal rot: an important disease of sunflower and its control. Progr Farm 10(6): 34-36.

7. Shah NA, Aujla KM, Ishaq $M$ \& Farooq A (2013). Trends in sunflower production and its potential in increasing domestic edible oil production in Punjab, Pakistan. Sarhad J Agri 29(1): 7-13.

8. Ashraf A, Ristina SS, Asad M, Hasan M, Qamar H, Mudassar M, Raza MU, Anum W, Abbasi WM \& Arshad A (2019). Variability and correlation study of different newly developed sunflower hybrids in Pakistan. Int $J$ Biosci 14(2): 398-408.

9. Rajamohan N (1976). Pest complex of Sunflower. A bibliography. PANS, 22(4): 546-563.

10. Ahmed KN (2002). Use of biopesticide in the control of the pests of oilseeds in preharvest and postharvest conditions. Research Report submitted to the
Ministry of Science and Information and communication Technology.

11. Aslam M, Suleman N, Riaz A \& Rehman A Zia Q (2000). Insect Pests found on Helianthus annuus $\mathrm{L}$. (Compositae) in the Potohar Region of Pakistan. Pak J Biolog Sci 3(6): 963964.

12. Wakil W, Ghazanfar MU, Kwon YJ, Qayyum MA \& Nasir F (2010). Distribution of Helicoverpa armigera Hübner (Lepidoptera: Noctuidae) in tomato fields and its relationship to weather factors. Entomol Res 40(6): 290-297.

13. Manjunath TM, Bhatnagar VS, Pawar CC \& Sithanatham S (1985). Economic importance of Heliothis spp. in India and an assessment of their natural enemies and host plants. In: Proceed Biol Cont Heliothis: Increasing effectiveness of natural enemies, New Delhi, India. 197-228.

14. Ranasingh N \& Mahalik JK (2008). Insect pests management in sunflower. Orissa Rev 51-52.

15. Anonymous (2014). Pest of sunflower, Insect Pest Captulum borer, Oilseeds, Agropedia.

16. Arora RK, Yaqoob $M$ \& Ishar $A$ (2003). Status of pyrethroid resistance in Helicoverpa armigera in India. Resist Pest Manag Newsletter 12(2): 64-65.

17. Kranthi KR, Jadhav DR, Wanjari RR, Kranthi S \& Russell DA (2001). Pyrethroid resistance and mechanisms of resistance in field strains of Helicoverpa armigera (Lepidoptera: Noctuidae). J Eco Entomol 94: 253263.

18. Nasreen A, Mustafa G \& Ashfaq M (2003). Selectivity of some insecticides to Chrysoperla carnea (Stephen) (Neuroptera: Chrysopidae) in laboratory. Pak J Biol Sci 6(6): 536538.

19. Zubair M, Ahmed S, Cheema SA, Bashir MR, Maan NA \& Aslam A (2018). Susceptibility status of 
sunflower hybrids against whitefly, Jassid and head moth under natural field conditions in Pakistan. Int $J$ Entomol Res 3(2): 65-68.

20. Ali S, Zubair M, Saleem MJ, Hussain D, Hafeez F, Ayub MA, Maan NA, Malik MK \& Aftab M (2019). Response of advanced sunflower hybrids to head moth infestation. $J$ Entomol Zool Stud 7(2): 600-602.

21. Visnupriya $\mathrm{M} \&$ Muthukrishnan $\mathrm{N}$ (2017). Acute toxicity and field evaluation of spinetoram $12 \mathrm{SC}$ against Helicoverpa armigera Hubner on tomato. J Ent Zool Stud 5(5):16081613.

22. Akbar W, Asif MU, Memon RM, Bux M \& Sohail M (2018). Validation of some new chemistry and conventional insecticides against gram pod borer (Helicoverpa armigera) in chickpea. Pak Entomol 40(1): 45-49.

23. Abbas G, Hassan N, Farhan M, Haq I \& Karar H (2015). Effect of selected insecticides on Helicoverpa armigera Hubner (Lepidoptera: Noctuidae) on tomato (Lycopersicon esculentum Miller) and their successful management. Adv Entomol 3(1): 1623.

24. LI YN, GENG P, HU MY \& HU Z (2012). Field Efficacy of LambdaCyhalothrin and Chlorantraniliprole
150g/L ZC against Heliothis armigera of Tomato. Hubei Agric Sci pp 8.

25. Iqbal J, Farooq SU, Jamil M, Khan HAA \& Younis M (2014). Relative efficacy of selective insecticides against gram pod borer (Helicoverpa armigera H.) of chickpea. Mycopath 12(2): 119-122.

26. Younis M, Iqbal J, Farooq SU, Jamil M \& Khan HAA (2015). Relative efficacy of selective insecticides against gram pod borer (Helicoverpa armigera $\mathrm{H}$.) of chickpea. Mycopath 12(2): 119122.

27. Khan MM, Nawaz M, Cheema SA \& Salah-ud-Din S (2014). Comparison of new chemistry and conventional insecticides against Helicoverpa armigera on sunflower (Helianthus annuus). J Agric Res 52(4): 555-559.

28. Hanafy HE \& El-Sayed W (2013). Efficacy of bio-and chemical insecticides in the control of Tuta absoluta (Meyrick) and Helicoverpa armigera (Hubner) infesting tomato plants. Aust J Basic Appl Sci 7(2): 943948.

29. Ramasubramanian $\mathrm{T} \&$ Regupathy A (2004). Evaluation of indoxacarb against Pyrethroid resistant population of Helicoverpa armigera Hub. $J$ Entomol 1(1): 21-23. 